\title{
THE INCLUSIVE DEVELOPMENT CONCEPT AS A MODERN PARADIGM FOR INTENSIFICATION OF IMPLEMENTATION OF INNOVATIONS
}

\author{
Oksana Prodius ${ }^{1}$
}

\begin{abstract}
The aim of the article is to generalize the approaches to the definitions of inclusive economic development as a modern paradigm of intensification of innovation. The main methodological method of research is a system-structural approach that allows you to most effectively organize the search to solve problems. Methods of comparative, functional analysis, classification are also used. The theoretical basis of the article has been the conceptual provisions and scientific principles developed by domestic and foreign scientists on issues of inclusive economic development, tools for its implementation. However, the problems related to the development and implementation of an effective mechanism for the implementation of the inclusive economy in the context of the intensification of innovative development remain incomplete. The importance and significance of these issues led to the choice of the topic of the article, setting the purpose and objectives of the study. The main indicators of Ukraine's inclusive development are analysed and the factors hindering the inclusion effective development are identified. The adoption of a new system for assessing economic development by the world community will help to adjust the domestic policies of a number of states, which will contribute to international economic integration and the development of the methodological framework of national and international statistics bodies. It has been found that 11 indicators out of 12 in Ukraine have a negative trend. Among them, the largest decline has been observed in labor productivity and the share of public debt in GDP. One of the most important obstacles to inclusive economic development has been found to be high levels of inequality, which limit access to education for different groups and negatively affect the labor market, which is filled annually with low-skilled labor. Expanding quality and access to education plays a crucial role in overcoming this barrier. It has been proven that the concept of inclusive development can best ensure the implementation of the principles of sustainable and balanced development, while avoiding such threats as: crises related to lack of resources and limited access to them; increasing social inequality and poverty; exclusion of certain marginal groups from the political, economic and social life of society; rising unemployment; social and political conflicts; environmental crises. The relevance of inclusive innovations for the economy development is substantiated and the directions of state policy are formed to ensure inclusive innovation development. The directions of cooperation between the state and business are proposed to ensure not only inclusive economic development, but also its connection with public investment policy, which would reduce the level of inequality in society and contribute to improving the citizens' well-being.
\end{abstract}

Key words: inclusive development, economic growth, innovation process, inequality, Inclusive Development Index, inclusive innovations, education, business.

JEL Classification: E61, F62, O33

\section{Introduction}

The effective management of modern socioeconomic systems development is closely linked to the problems of their stable and balanced development. In the context of global economic instability, there is a fundamental need to rethink and change existing models of economic growth in

\footnotetext{
Corresponding author:

${ }^{1}$ Odessa National Polytechnic University, Ukraine.

E-mail: o.i.prodius@gmail.com

ORCID: https://orcid.org/0000-0002-0619-7567
}

order to overcome growing socioeconomic inequalities. Having realised most of its growth potential, the global economic system at the present stage of social development requires the transformation of economic relations structure in order to create new opportunities for economic growth. To achieve this, we need to focus on 
solving social problems and achieving a new stage of scientific and technological progress. The tendency of the global economy towards stagnation is accompanied by uneven income distribution and accumulated wealth among the population and is a consequence of growing social tensions around the world. The slowdown in economic growth, is characteristic not only of a number of developing countries, but also for developed countries, is intensifying efforts to find a new model of socioeconomic development that can meet the current challenges facing the economy and society. From this viewpoint, the inclusive development concept can best ensure the principles implementation of sustainable and balanced development, while avoiding such threats as: crises related to lack of resources and limited access to them; increasing social inequality and poverty; exclusion of certain marginal groups from the society's political, economic and social life; rising unemployment; social and political conflicts; ecological crises.

\section{Analysis of recent researches and publications}

In the scientific community and management practice, interest in inclusive development has increased. Numerous publications addressing issues of "inclusiveness" from different positions and in different spheres appear. The issues of inclusive economic development, apparatus for its implementation and related problems have been actively studied in the researches of such foreign scholars as D. Acemoglu, D. Robinson, J. Gupta, N. Pauv, M. Ross-Tonen, J. Podesta, J. Chataway, R. Hanlin, R. Kaplinsky, R. Heeks, C. Foster, J. Nugroho, N. Pakhomova, K. Richter, G. Malyshkov. Such domestic scientists as A.V. Bazyliuk, O.V. Zhulyn, A.A. Hrytsenko, L.I. Fedulova, T.H. Zatonatska, M.A. Pyvovarova, S.A. Sapun, A.A. Urunov, O.H. Vdovichena, I.H. Mantsurov have made a significant contribution to the coverage of inclusive development various aspects. However, a number of problems concerning the development and implementation of effective mechanism of the inclusive economic growth realization in the context of innovative development intensification remain incomplete, that is why the necessity of detailed study of proposed issue arises. The importance and significance of these issues led to the choice of topic, goal setting and objectives of the study.

\section{Inclusive development}

The term "inclusion" is the process of increasing the participation degree of all the citizens in society (as a whole social system), aimed at equality development. The economic essence of the inclusiveness concept is most fully considered in the works of famous modern economists J. Robinson and D. Acemoglu: inclusive is for the involvement of all in the process, without differences and limitations (The Inclusive Growth and Development Report 2017).

The definition of this term can be found in Project 3.0 "Sustainable Development Strategy for Ukraine by 2030": inclusiveness (from lat. Include - engage, subside) is the participation process of all people in the life of society, where all the stakeholders are actively involved in public life. Inclusiveness provides for the inclusion of everyone in the life of the community and any discrimination absence" (Zadoja, 2019).

The relevance of the topic of inclusive economic development for Ukraine is primarily due to the peculiarities of the state's economic model, namely the markets reorientation, the economy withdrawal out of stagnation and uneven development of the country's regions, signs that point to the deindustrialization development, the subsidized nature of conducting business in some sectors, and a large proportion of the socially disadvantaged population. The fact that the country's economic growth is taking place against the background of increasing poverty complicates the situation.

\section{The inclusive development index}

In 2018, the World Economic Forum in Davos adopted the Inclusive Development Index (IDI), a new system for assessing countries' economic development, which is an relevent tool for measuring a state's level of socio-economic development. For political leaders, IDI can be a new guideline for effective domestic policies aimed at reducing social inequality and achieving sustainable economic development. The index is calculated on the basis of 12 indicators, which are divided into three groups. Herewith, each indicator is analysed in parallel with the calculations for the last 5 years. This allows us to identify the main trends in the national economic system (The Inclusive Growth and Development Report 2017; Zadoja, 2019). The inclusive development index is calculated separately for the economies of developed and developing countries, which increases the objectivity of the received results (Table 1). 
Table 1

The indicators of inclusive economic development

\begin{tabular}{|c|c|c|}
\hline No & The group name & The Indicators \\
\hline 1. & Growth and development & $\begin{array}{l}\text { - GDP per capita; } \\
\text { - labour efficiency - GDP per employee (in USD); } \\
\text { - average life expectancy; } \\
\text { - working-age population employment }\end{array}$ \\
\hline 2. & Inclusiveness & $\begin{array}{l}\text { - income distribution ratio in society ( } 0 \text { - complete equality, } 100 \text { - complete inequality); } \\
\text { - poverty level; } \\
\text { - the society's stratification coefficient by the wealth distribution ( } 0 \text { - complete equality, } \\
100 \text { - complete inequality); } \\
\text { - median daily household expenditure(an indicator based on purchasing power, which divides } \\
\text { the country's population into two halves: those who spend above and below this level). }\end{array}$ \\
\hline 3. & $\begin{array}{l}\text { Intergenerational } \\
\text { resillience and } \\
\text { development sustainability }\end{array}$ & $\begin{array}{l}\text { - adjusted net savings (calculated according to the scheme: stocks of natural resources plus } \\
\text { expenditures on education and minus resources consumption, energy reserves depletion, } \\
\text { damage from emissions, are indicated as a percentage of gross national product); } \\
\text { - GDP greenhouse effect (the } \mathrm{CO}_{2} \text { emissions indicator for every dollar of gross domestic } \\
\text { product produced by the country's economy); } \\
\text { - the amount of public debt (as a GDP percentage); } \\
\text { - demographic burden (the ratio of dependent citizens aged } 0 \text { to } 15 \text { and over } 64 \text { to the total } \\
\text { working population). }\end{array}$ \\
\hline
\end{tabular}

The Inclusive Development Index, as a system for assessing the state's level of socio-economic development, provides extensive information on the condition of the economic system and serves as a new guideline necessary for the effective domestic policy formation. The adoption by the world community of a new system for assessing economic development will help to adjust the domestic policies of a number of states, which will contribute to international economic integration and the methodological framework development of national and international statistics bodies. It opens new opportunities for the concept implementation of inclusive growth, achieving sustainable economic development, as well as solving social and economic problems in countries.

It should be noted that from 11 indicators in Ukraine out of 12 have a negative trend data. Among them, the largest decline has been observed in labour productivity and the share of public debt in GDP. It has been found out that due to the large share of the shadow sector in Ukraine's economy, the indicator the "society stratification by income distribution" does not reflect reality. Excessive markets monopolization in Ukraine is also relevant, which is reflected in the wealth distribution ratio, whichg is one of the worst indicators among developing countries. The situation with core capital depreciation, which is reflected in the indicator of "adjusted net stocks", requires immediate intervention at the legislative level. The coefficient of demographic burden has increased, which indicates the further hopelessness of the pay-as-you-go pension system application. It is the only indicator that shows a positive trend is the greenhouse gas emissions intensity. This is explained by the fact that Ukraine is on the path of deindustrialization and is gradually becoming an agro-industrial country with a dominant raw materials (Prodius, 2017).

Thus, one of the most important obstacles to inclusive economic development is the high level of inequality, which limits access to education for different population groups and negatively affects the labour market, which is annually filled with low-skilled labour power. In order to overcome this obstacle, a crucial role plays expanding access to education and its quality improvement. As experience shows, employment policy measures, such as raising the minimum wage and expanding social protection, make it possible to increase the living standards of low-income people. In addition, poverty reduction and the gap between town and village can also help to prioritize rural infrastructure development through public investment in transport, agriculture and energy. The "green" industrial enterprises creation depends on the availability of qualified specialists with higher education and training in specific fields. The greening of existing industrial enterprises requires the organization of a continuous process of education and training, often in off-work hours, 
for low- and middle-skilled employees. Providing sustainable development and inclusive economic growth require a significant increase of investments amount in the research and development, namely into inclusive innovations.

\section{Inclusive innovations}

According to domestic scientist L. I. Fedulova, inclusive innovations are aimed at "creating and bringing to market new quality products or services that are designed for and / or those who are deprived of a decent living standard (for example, for low-income people, disabled people, migrants, retirees and others" (Fedulova, 2016).

The main purpose and goal of innovations are economic progress and improving the welfare of various groups in society. However, due to their specificity, innovations can be a factor in society's stratification and social inequality emergence. That is why the issue of "inclusive" innovations is becoming relevant. They focus on improving the welfare of poor and marginalized groups, particularly in the areas of education, infrastructure and health care.

So, the primary goal of inclusive innovations is to provide the poor segment of population with basic goods and primary necessity services. Today, however, inclusiveness is about creating mechanisms to involve the marginalized youth, disabled people, people living in distant regions, in the joint development and implementation of inclusive solutions, i.e., active participation in overcoming threats of economic security.

Inclusive innovations are aimed at stimulating and encouraging human development and improving the population's welfare; inclusion in the socioeconomic life of all the population groups, including the most marginalized, i.e., those whose way of life does not meet the standards inherent in the society to which theybelong, but does not violate its legal norms; poverty and inequality reduction; increasing and activization of the individual groups' participation in the oeconomic processes management, not only in their distribution results; contributing sustainable management of natural resources and climate protection at the global level.

The World Bank defines the inclusive innovative activities as any innovative activities that help to expand easy access to quality products and services, creating and increasing opportunities for the marginalized population segments to receive funds. It identifies five characteristics features of inclusive innovative activities: acceptable access; sustainable production; goods and services that create opportunities to earn a living; targeting marginalized population segments, especially disabled people (Prodius, 2017). Inclusive innovative activities are based not only on technological innovations, but also on the automation of work processes, delivery systems and innovations in business processes to reduce costs and expand access. It means that inclusive innovations can be developed on the basis of advanced researches or using previously known technologies. Inclusive innovative activities are aimed primarily at promoting access to basic goods and services and expanding economic rights and opportunities through efforts in creation, acquiring, adaption, assimilation and dissemination of knowledge directly focused on meeting the needs of marginalized population segments (Vdovichena, 2018; Vdovichen, Vdovichena, 2017). Inclusive innovative activities also include the development, dissemination and implementation of innovations that can improve the living conditions of disadvantaged groups who are not low-income people.

Within the framework of inclusive development, most authors recognize that for inclusive growth it is necessary to develop, implement and monitor the inclusive growth strategies, focusing on the long term, by building strong local and national institutions. Namely leadership in the field of highly efficient innovative technologies in such areas as information, space, industrial technologies, biotechnology, nanotechnology, new substances development will determine the competitive position of national economies in the global market. For this reason, current global trends in inclusive development are identified by priorities, in which innovation is given considerable attention:

1. Demographic change, living standards and health.

2. Food security, rational agriculture, seabed research, bioeconomics.

3. Safe, clean and efficient electrical industry.

4. Energy efficient green transport.

5. Climate change resilience, efficient use of resources and natural endowments.

6. An innovative, reflective society of equal opportunities.

7. Safe society (Pereghudova, 2016; Mancurov, 2018).

Therefore, taking into account all the above mentioned aspects, it makes sense to say that inclusive development can be considered as 
a development that inherits multidimensionality within the environment formed by the state, society and business, integration and interaction of which create interconnected institutions focused on the long term, ensuring a balanced distribution of tangible and intangible benefits among the society's members, taking into account future generations' needs.

Researchers consider that the private sector is able to help improve the living conditions of disabled people in three main ways: by means of creating jobs and increasing productivity, by means of meeting some of their needs through corporate social responsibility initiatives and by means of developing affordable products and services that meet the needs of low-income consumers. Inclusive innovative policy is aimed to enable disabled people to participate in inclusive innovative activities, either as innovators or as users of innovations.

It is the inclusive development concept that sets aside the population's broad involvement in the development results distribution, while simultaneously focusing on the active introduction of innovations and not only on quantitative indicators, but also qualitative indicators of social inclusion and environmental sustainability, which makes it possible to talk about a non-discriminatory economy that works for the whole of society, i.e., an inclusive economy. Inclusive development will contribute to the effects of multidimensional inclusion, such as: restrictions, poverty rate reduction and the social strata expansion of the middle class; branching employment and increasing productivity by adapting to individual human capabilities and requirements; increasing the population's welfare; improving the quality of human capital; supporting the ecological balance; controlling and reducing macroeconomic, territorial and social disparities; formation of a safe economic, political, legal, ecological environment.

\section{Conclusions}

The main purpose of the inclusive economic development concept will be solving the problem of reaching a surplus of foreign trade transictions balance, achieving relative equality of savings and investment, increasing Ukraine's investment attractiveness, reducing social tensions, creating new jobs, innovations introduction. At the same time, it should be noted that in the process of implementing the concept of inclusive economic development a special role should be given to the vulnerable groups' involvement in society, their employment, integration into economic processes of youths and disabled people. Anintegtal partnershipin the context of inclusive economic development is possible only if there is a common, shared understanding of the development mechanisms, on opinions consistency on the society's need for an inclusive approach, including inclusive innovations, as an instrument to enhance a state's economic security. The inclusive development concept in the context of inclusive innovations effective implementation can most fully ensure the principles realisation of stable and balanced economic development, while avoiding such threats as: resources related crises; increasing social inequality and poverty; exclusion of certain marginal groups from the society's economic and social life; increasing unemployement. Namely inclusive innovations have the opportunity to become a stimulus and a positive trend of economic progress and are designed to help improve the welfare of various groups in society.

\section{References:}

The Inclusive Growth and Development Report 2017: Insight Report the World Economic Forum. January 2017. Retrieved from: http://www3.weforum.org/docs/WEF_Forum_IncGrwth_2017.pdf (accessed: 05 May 2020).

Zadoja, O. A. (2019). Instrumenty ta naprjamy realizaciji strateghiji inkljuzyvnogho rozvytku v Ukrajini [Apparatus and directions of inclusive development strategy implementation in Ukraine]. Akademichnyj oghljad, vol. 2(51), pp. 5-14.

Prodius, O. I. (2017). Inkljuzyvni innovaciji v konteksti socialjnoji vidpovidaljnosti pidpryjemstva [Inclusive Innovations in the context of social responsibility of the enterprise]. Naukovyj visnyk Uzhghorodsjkogho nacionaljnogho universytetu, vol. 14, pp. 84-88.

Fedulova, L. I. (2016). Inkljuzyvni innovaciji v systemi socialjno-ekonomichnogho rozvytku [Inclusive innovations in the system of socioeconomic development]. Ekonomika: realiji chasu, vol.3(25), pp. 56-65. Vdovichena, O. Gh. (2018). Inkljuzyvnyj rozvytok - suchasna paradyghma stijkogho ekonomichnogho zrostannja [Inclusive development - a modern paradigm of sustainable economic growth]. Visnyk Chernivecjkogho torghoveljno-ekonomichnogho instytutu. Ekonomichni nauky, vol. 3, pp. 17-29. 
Vdovichen, A. A., \& Vdovichena, O. Gh. (2017). Dysproporcijnistj innovacijnykh naprjamkiv strukturnoji perebudovy promyslovosti Ukrajiny: ghoryzontaljnyj ta sektoraljnyj pidkhody [Dispropority of innovative sectors of structural reorganization of the industry of Ukraine: horizontal and sectoral approaches]. Visnyk Chernivecjkogho torghoveljno-ekonomichnogho instytutu. Ekonomichni nauky, vol. 3, pp. 27-39.

Proghnimak, O. D. (2018). Inkljuzyvnyj rozvytok Ukrajiny: pereshkody vs perspektyvy [The inclusive development of Ukraine: obstacles vs prospects]. Ekonomichnyj visnyk Donbasu, vol. 1(51), pp. 187-197. Pereghudova, T. V. (2016). Socialjna inkljuzija jak element socialjnoji polityky: Jevropejsjki uroky dlja Ukrajiny [Social Inclusion as an element of social policy: european lessons for Ukraine]. Naukovyj visnyk Mizhnarodnogho ghumanitarnogho universytetu, vol. 19, pp. 98-102.

Mancurov, I. Gh. (2018). Inkljuzyvnyj rozvytok jak osnova protydiji vyklykam sjoghodennja [Inclusive growth as a basis for countering the global challenges of nowadays]. Ekonomika Ukrajiny, vol. 10(683), pp. $71-87$. 